\author{
Нікішина О.В. \\ доктор економічних наук, старший науковий співробітник \\ відділ ринкових механізмів та структур \\ Інститут проблем ринку та економіко-екологічних досліджень НАН України \\ Французький бульвар, 29, м. Одеса, Україна, 65044 \\ E-mail: ksenkych@gmail.com
}

\title{
МЕТОДИЧНІ ПОЛОЖЕННЯ ЩОДО МОНІТОРИНГУ ІНДИКАТОРІВ «ЗЕЛЕНОГО» ЗРОСТАННЯ У КОНТЕКСТІ СТАЛОГО РОЗВИТКУ УКРАЇНИ
}

У статті обґрунтовано методологічний підхід до моніторингу «зелених» індикаторів на засадах сталого розвитку у двоєдності концептуального та методичного базисів, визначено наукові принципи моніторингу прогресу «зеленого» зростання. Автором запропоновано розширену систему економікоекологічних індикаторів для оцінки досягнення другої Цілі сталого розвитку «Подолання голоду, розвиток сільського господарства» з акцентом на групу показників органічного землеробства, використання добрив та стану ґрунтів. 3 використанням розробленої системи індикаторів проведено моніторинг їх стану в Україні за період 2005-2017 рр., що дозволило визначити динаміку їх змін, базисні й ланцюгові індекси, ступінь досягнення цільового значення показників. На базі результатів моніторингу здійснено якісний аналіз і діагностику економіко-екологічних показників, визначено домінуючі тенденції їх змін та механізми стимулювання процесу «зеленої» трансформації національної економіки.

Ключові слова: моніторинг, «зелене» зростання, сталий розвиток, індикатори, оцінка, діагностика, «зелена» трансформація.

This work is licensed under a Creative Commons Attribution 4.0 International License http://creativecommons.org/licenses/by/4.0/

Постановка проблеми та її зв'язок з важливими науковими та практичними завданнями. В умовах обмеженості природних ресурсів виникає необхідність впровадження нових моделей економічного зростання, які забезпечують тісну взаємодію між економікою, природним середовищем та соціумом. Згідно з глобальним Порядком денним в галузі розвитку на період до 2030 року, прийнятим 193 країнамичленами ООН на Саміті зі сталого розвитку у вересні 2015 р., інклюзивна трансформаційна економіка, що базується на стійких структурах виробництва i споживання, є важливим чинником забезпечення нової динаміки розвитку [1]. Водночас імплементація 17 Цілей Сталого Розвитку (далі - ЦСР), прийнятих на цьому Саміті, вимагає системного підходу до «зеленої» трансформації економіки та здійснення моніторингу.

Моніторинг представляє собою динамічну систему спостережень, збору, обробки та аналізу інформації про стан впровадження ЦСР, що формують основу «зеленої» економіки. Об’єктивний і системний моніторинг «зеленого» прогресу формує аналітичний фундамент для прийняття науково обгрунтованих управлінських рішень щодо напрямів і методів стимулювання «зеленого» зростання, прогнозування динаміки його розвитку, ідентифікації «вузьких» місць у процесі тощо. Завдання багаторівневої оцінки напрямів трансформації вітчизняної економіки крізь призму «зеленого» зростання обумовлює необхідність розробки нового методичного забезпечення, яке, базуючись на результатах адаптації 17 глобальних ЦСР з урахуванням специфіки націо- нального розвитку [2], методиці Організації економічного співробітництва та розвитку (ОЕСР) [1], передбачає інтеграцію «зелених» індикаторів у систему соціально-економічних показників сталого розвитку України та конструювання нових показників для більш глибокої оцінки стану й динаміки змін «зеленого» прогресу.

Аналіз останніх публікацій по проблемі. Теоретико-методичні засади моніторингу ЦСР в Україні висвітлені в Національній доповіді Міністерства економічного розвитку i торгівлі України 2017 року [2]. Вони апробовані в регіональному вимірі вченими ДУ «Інститут регіональних досліджень ім. M.I. Долішнього НАН України», зокрема, I. Сторонянською, В. Борщевським, М. Мельник, С. Шульц та іншими [3]. Методичні підходи до оцінки «зеленої» трансформації в Україні на основі показників ОЕСР запропоновані Л. Мусіною та Т. Квашою [1]. Водночас додаткових інноваційних досліджень потребує питання методичного забезпечення моніторингу ЦСР у контексті «зеленого» зростання, розширення системи оціночних показників за рахунок як «зелених» індикаторів ОЕСР, так і нових авторських показників, що враховують специфіку економіко-екологічного розвитку України.

Формулювання цілей дослідження. Мета статті - розробка методичних положень щодо моніторингу індикаторів «зеленого» зростання на засадах сталого розвитку та їх апробація на прикладі другої Цілі сталого розвитку «Подолання голоду, розвиток сільського господарства» - окреслила низку завдань:

1) обгрунтування методологічного підходу до 
моніторингу «зелених» індикаторів у двоєдності концептуального та методичного базисів;

2) розробка та апробація у державному вимірі системи показників для оцінки досягнення другої ЦСР у розрізі їі головних завдань;

3) якісний аналіз динаміки змін економікоекологічних показників, діагностика досягнення дру- гої ЦСР в українських реаліях.

Виклад основних результатів та їх обгрунтування. Методологічний підхід до моніторингу індикаторів «зеленого» зростання, що пропонується автором, поєднує концептуальний і методичний базис, складові яких наведено на рис. 1.

\section{Кон ие п ту уальнй̈ базис}

Концепції сталого розвитку, зеленого зростання, інклюзивного зеленого зростання

Мета методичних положень: моніторинг досягнення ЦСР, що формують основу «зеленої» економіки, вимірювання прогресу зеленого зростання, як методичний базис прийняття виважених управлінських рішень для забезпечення «зеленої» трансформації національної економіки

Завдання методичних рекомендацій:

1. Систематизація інформаційних потоків у розрізі головних напрямів оцінки

2. Аналіз стану й динаміки економіко-екологічних показників зеленого зростання у розрізі Цілей Сталого Розвитку $2,6,7,8,9,11,12,15$.

3. Оцінка взаємозв'язку та кореляції різних індикаторів як у межах певної ЦСР, так і показників різних ЦСР

4. Оцінка взаємовпливу економічних показників на екологічні індикатори сталого розвитку, взаємозалежності макроекономічних показників й індикаторів зеленого зростання

5. Визначення за результатами оцінки негативних тенденцій у процесі «зеленої» трансформації економіки, чинників, що гальмують прогрес «зеленого» зростання в державі

6. Узагальнення та якісна оцінка результатів аналізу, як база для прийняття управлінських рішень щодо розвитку «зеленої» економіки

7. Прогнозування розвитку процесу «зеленої» трансформації, динаміки індикаторів «зеленого» зростання Приниипи моніторингу прогресу «зеленого» зростання

\begin{tabular}{|c|c|}
\hline $\begin{array}{l}\text { 1. Системність } i \\
\text { комплексність }\end{array}$ & $\begin{array}{l}\text { Оцінка становлення «зеленої» економіки як складної динамічної системи проводиться } \\
3 \text { урахуванням всіх внутрішніх і зовнішніх зв’язків між її елементами та їх взаємозале- } \\
\text { жності, забезпечуючи всебічне дослідження причинних залежностей в економічній } \\
\text { системі }\end{array}$ \\
\hline $\begin{array}{l}\text { 2.Адекватність } i \\
\text { гнучкість }\end{array}$ & $\begin{array}{l}\text { Забезпечення можливості швидкого реагування та врахування змін у зовнішньому і } \\
\text { внутрішньому економічному просторі, відповідність способів і прийомів аналізу су- } \\
\text { часним закономірностям плинності процесів відтворення в циркуляційній економіці }\end{array}$ \\
\hline $\begin{array}{l}\text { 3.Об'єктивність } i \\
\text { точність }\end{array}$ & $\begin{array}{l}\text { Інформаційна база для оцінки повинна бути достовірною, а її результати обгрунтову- } \\
\text { ватися точними аналітичними розрахунками }\end{array}$ \\
\hline 4. Дієвість & $\begin{array}{l}\text { Результати оцінки досягнення ЦСР повинні мати прикладне значення, слугувати базою } \\
\text { для прийняття заходів щодо стимулювання «зеленого» зростання, для аналізу зворот- } \\
\text { ної реакції «зелених» видів діяльності на заходи державного впливу }\end{array}$ \\
\hline 5. Цілеспрямованість & $\begin{array}{l}\text { Цільове визначення «вузьких місць» у розвитку «зелених» видів діяльності, які є дже- } \\
\text { релом дезінтеграції елементів системи }\end{array}$ \\
\hline $\begin{array}{l}\text { 6.Пріоритетність } \\
\text { економічних інте- } \\
\text { ресів держави }\end{array}$ & $\begin{array}{l}\text { Оцінка ефективності «зелених» видів діяльності та регуляторних заходів здійснюється } \\
\text { не з позиції економічних інтересів окремих суб'єктів господарювання, а держави як } \\
\text { носія інтересів суспільства; даний принцип є головним і в прийнятті управлінських } \\
\text { рішень щодо впливу на процес «зеленої» трансформації економічної системи }\end{array}$ \\
\hline 7. Науковість & $\begin{array}{l}\text { Постійне удосконалення методик моніторингу досягнення ЦСР та використання пере- } \\
\text { дового світового досвіду щодо оцінки прогресу «зеленого» зростання }\end{array}$ \\
\hline & Методичний ба \\
\hline
\end{tabular}

1. Оиінка досягнення ЦСР за допомогою системи соиіально-економічних показників, в яку інтегровані індикатори «зеленого» зростання. Перелік ЦСР:

Ціль 2. Подолання голоду, розвиток сільського господарства

Ціль 6. Чиста вода та санітарні умови

Ціль 7. Доступна та чиста енергія

Ціль 8. Гідна праця та економічне зростання

Ціль 9. Промисловість, інновації та інфраструктура

Ціль 11. Сталий розвиток міст і громад

Ціль 12. Відповідальне споживання та виробництво

Ціль 15. Захист та відновлення екосистем суші.

2. Аналіз взаємовпливу економічних індикаторів на стан і динаміку «зелених» індикаторів

3. Діагностика досягнення ЦСР, якісний аналіз причинно-наслідкових зв'язків, що визначають процеси «зеленої» трансформації економіки; прогнозні сценарії розвитку «зеленої» економіки Пріоритети національної екологічної політики, стратегічні орієнтири «зеленого» зростання держави

\begin{tabular}{ll}
\hline \multicolumn{3}{c}{ Механізми регулювання розвитку «зеленої» трансформації економіки: } \\
$\begin{array}{ll}\text { 1. Адміністративні } & \text { 3. Інституційні } \\
\text { 2. Фінансово-економічні } & \text { 4. Інформаційні }\end{array}$ \\
\hline
\end{tabular}

Рис. 1. Структурна схема методологічного підходу до моніторингу індикаторів «зеленого» зростання на засадах сталого розвитку [авторська розробка] 
Головною метою методичних положень є моніторинг досягнення ЦСР, що формують основу «зеленої» економіки (Цілі 2, 6, 7, 8, 9, 11, 12, 15), вимірювання прогресу «зеленого» зростання, як методичний базис прийняття управлінських рішень для забезпечення «зеленої» трансформації економіки. Слід відзначити, що концепція «зеленого» зростання не підміняє концепцію сталого розвитку, а виступає практичним інструментом досягнення ЦСР. Невід'ємною складовою методологічного підходу $\epsilon$ принщипи моніторингу прогресу «зеленого» зростання, до складу яких автором віднесено наступні: (1) системність і комплексність; (2) адекватність і гнучкість; (3) об'єктивність і точність; (4) дієвість; (5) цілеспрямованість; (6) пріоритетність економічних інтересів держави; (7) науковість.

Методичний базис включає методичні положення щодо моніторингу індикаторів «зеленого» зростання на засадах сталого розвитку, оцінку впливу економічних показників та стан і динаміку екологічних індикаторів, діагностику «зеленого» прогресу, як основу для прийняття управлінських рішень щодо напрямів і механізмів регулювання, узгоджених із пріоритетами національної екологічної політики й стратегічними орієнтирами «зеленого» зростання держави (див. рис. 1).

Базовим фундаментом для конструювання системи соціально-економічних показників є множина індикаторів, що оцінюють досягнення визначених ЦСР у розрізі певних завдань [2]. Розширення даної системи здійснюється шляхом інтеграції індикаторів «зеленого» зростання ОЕСР [1] та нових показників, розрахованих за даними Державної служби статистики України. Враховуючи ці умови, автором запропонована система індикаторів для оцінки досягнення другої ЦСР в Україні (таблиця 1). Розширена система показників включила низку індексів, що оцінюють зміну індикаторів порівняно з базовим періодом та їх цільовим значенням 2020 р., динаміку структурних показників, а також розширену групу індикаторів органічного землеробства. Використовуючи запропоновану систему оціночних показників, проведемо оцінку ступеня досягнення другої ЦСЛ в Україні за період 2005-2017 pp.

Таблиця 1

Завдання й індикатори другої Цілі сталого розвитку «Подолання голоду, розвиток сільського господарства»"

\begin{tabular}{|c|c|}
\hline Завдання & Індикатори \\
\hline $\begin{array}{l}\text { 2.1. Забезпечити доступність } \\
\text { збалансованого харчування на } \\
\text { рівні науково обтрунтованих } \\
\text { норм для всіх верств населен- } \\
\text { ня }\end{array}$ & $\begin{array}{l}\text { 2.1.1. Споживання м’яса в розрахунку на одну особу, кг/рік } \\
\text { 2.1.2. Споживання молока в розрахунку на одну особу, кг/рік } \\
\text { 2.1.3. Споживання фруктів в розрахунку на одну особу, кг/рік } \\
\text { 2.1.4. Індекси споживання м’яса, молока та фруктів на одну особу; у \% до } \\
2005 \text { р., раціональної норми, цільового показника } 2020 \text { р. ** }\end{array}$ \\
\hline $\begin{array}{l}\text { 2.2. Підвищити вдвічі проду- } \\
\text { ктивність сільського госпо- } \\
\text { дарства, насамперед за раху- } \\
\text { нок використання інновацій- } \\
\text { них технологій }\end{array}$ & $\begin{array}{l}\text { 2.2.1. Продуктивність праці в сільському господарстві на одного зайнятого } \\
\text { 2.2.2. Індекс сільськогосподарської продукції : } \\
\text { а) за видами діяльності сільського господарства (рослинництво, тваринниц- } \\
\text { тво); } \\
\text { б) за категоріями виробників (підприємства, у т.ч. фермерські господарства; } \\
\text { господарства населення) } \\
\text { 2.2.3. Індекс продуктивності праці в сільському господарстві на одного за- } \\
\text { йнятого, у \% до } 2005 \text { р. ** } \\
\text { 2.2.4.Динаміка індексу сільськогосподарської продукції }(+,- \text { порівняно } 3 \\
\text { 2010 р., цільовим показником } 2020 \text { р.)** }\end{array}$ \\
\hline $\begin{array}{l}\text { 2.3.Забезпечити створення } \\
\text { стійких систем виробництва } \\
\text { продуктів харчування, шцо } \\
\text { сприяють збереженню екоси- } \\
\text { стем і поступово покрацу- } \\
\text { оть якість земель та грун- } \\
\text { тів, насамперед за рахунок } \\
\text { використання інноваційних } \\
\text { технологій }\end{array}$ & $\begin{array}{l}\text { 2.3.1. Індекс виробництва харчових продуктів, \% } \\
\text { 2.3.2.Частка продукції харчової промисловості та переробки аграрної сиро- } \\
\text { вини в експорті груп 1-24 УКТЗЕД, \% } \\
\text { 2.3.3. Частка органічних сільськогосподарських угідь у загальній площі } \\
\text { сільськогосподарських угідь } \\
\text { 2.3.4. Динаміка індексу виробництва харчових продуктів }(+,- \text { порівняно з } \\
\text { 2010 р., з цільовим показником } 2020 \text { р.)** } \\
\text { 2.3.5. Динаміка частки продукції харчової промисловості в експорту груп 1- } \\
\text { 24 УКТЗЕД (+, - порівняно з } 2010 \text { р., з цільовим показником } 2020 \text { р.)** } \\
\text { 2.3.6. Частка органічних сільськогосподарських угідь у загальній території } \\
\text { країни, \% } \\
\text { 2.3.7.Індекс площ органічних сільськогосподарських угідь, \% до } 2005 \text { р.** } \\
\text { 2.3.8.Індекс кількості органічних господарств в Україні \% до } 2005 p . * * \\
\text { 2.3.9. Динаміка частки органічних угідь у загальній площі с/г угідь (+, - по- } \\
\text { рівняно з 2005 р., цільовим показником } 2020 \text { р.)** } \\
\text { 2.3.10. Динаміка частки органічних угідь у загальній території країни (+, - } \\
\text { порівняно з } 2005 \text { р.)** }\end{array}$ \\
\hline
\end{tabular}


Продовження табл. 1

\begin{tabular}{|c|c|}
\hline Завдання & Індикатори \\
\hline & $\begin{array}{l}\text { 2.3.11. Частка удобреної площі у посівній площі СГП***, \% (за мінеральни- } \\
\text { ми й органічними добривами)** } \\
\text { 2.3.12. Динаміка частки удобреної площі у посівній площі СГП (за мінера- } \\
\text { льними й органічними добривами) (+, - порівняно з } 2005 \text { р.)** } \\
\text { 2.3.13. Обсяг внесених добрив (мінеральних і органічних) СГП на } 1 \text { га посі- } \\
\text { вної площі, кг/га ** } \\
\text { 2.3.14. Індекс внесених добрив (мінеральних і органічних) СГП на } 1 \text { га посі- } \\
\text { вної площі, \% до } 2005 \text { р.** } \\
\text { 2.3.15. Індекс внесених добрив (у видовому розрізі) СГП під урожай звітно- } \\
\text { го року, \% до } 2005 \text { р.** } \\
\text { 2.3.16. Зміна структури внесених мінеральних добрив СГП, \% (+, - порівня- } \\
\text { но з 2005 р.)** } \\
\text { 2.3.17. Внесення азотних та фосфорних добрив, т/1000 га* } \\
\text { 2.3.18. Баланс гумусу в грунтах України, т/га } \\
\text { 2.3.19. Баланс поживних речовин в грунтах України, т/га* }\end{array}$ \\
\hline $\begin{array}{l}\text { 2.4. Знизити волатильність } \\
\text { цін на продукти харчування }\end{array}$ & $\begin{array}{l}\text { 2.4.1. Індекс споживчих цін на продукти харчування (середньорічний) за } \\
\text { основними групами продуктів, \% } \\
\text { 2.4.2. Динаміка індексу споживчих цін на продукти харчування }(+,- \text { порів- } \\
\text { няно з } 2005 \text { р., } 3 \text { цільовим показником } 2020 \text { р.)** }\end{array}$ \\
\hline
\end{tabular}

*Складено автором із використанням джерел $[1,2] ;{ }^{* * *}$ Індикатор запропоновано автором;

*** СГП- сільськогосподарські підприємства.

Досягнення першого завдання - забезпечення доступності збалансованого харчування на рівні науково обтрунтованих норм для всіх верств населення передбачає розрахунок показників споживання основних продуктів харчування на одну особу (таблиця 2). За розрахунками, споживання м'яса й м'ясопродуктів в Україні у 2017 р. склало 51,7 кг./особу, збільшившись порівняно з 2005 р. на 32,2\%. Незважаючи на зростання, фактичний показник досягнув у звітному періоді всього 64,6\% від раціональної норми та $84,8 \%$ від цільового значення 2020 р.

Таблиця 2

Споживання основних продуктів харчування населенням України, кг/особу*

\begin{tabular}{|c|c|c|c|c|c|c|c|c|c|c|c|c|}
\hline \multirow{2}{*}{$\begin{array}{l}\text { Продукти } \\
\text { харчування }\end{array}$} & \multicolumn{9}{|c|}{ Роки } & \multicolumn{3}{|c|}{2017 рік у \% до: } \\
\hline & 2005 & 2010 & 2011 & 2012 & 2013 & 2014 & 2015 & 2016 & 2017 & 2005 & $\mathrm{PH}^{* *}$ & Ц3 $3^{* * *}$ \\
\hline $\begin{array}{l}\text { 1. М'ясо і } \\
\text { м'ясопроду } \\
\text { кти }\end{array}$ & 39,1 & 52,0 & 51,2 & 54,4 & 56,1 & 54,1 & 50,9 & 51,4 & 51,7 & 132,2 & 64,6 & 84,8 \\
\hline $\begin{array}{l}\text { Темп росту, } \\
\text { пункти }\end{array}$ & $X$ & $X$ & 0,985 & 1,063 & 1,031 & 0,964 & 0,941 & 1,010 & 1,006 & $X$ & $X$ & $X$ \\
\hline $\begin{array}{l}\text { 2. Молоко і } \\
\text { молочні } \\
\text { продукти }\end{array}$ & 225,6 & 206,4 & 204,9 & 214,9 & 220,9 & 222,8 & 209,9 & 209,5 & 200,0 & 88,7 & 52,6 & 74,1 \\
\hline $\begin{array}{l}\text { Темп росту, } \\
\text { пункти }\end{array}$ & $X$ & $X$ & 0,993 & 1,049 & 1,028 & 1,009 & 0,942 & 0,998 & 0,955 & $X$ & $X$ & $X$ \\
\hline $\begin{array}{l}\text { 3.Плоди, } \\
\text { ягоди та } \\
\text { виноград } \\
\end{array}$ & 37,1 & 48,0 & 52,6 & 53,3 & 56,3 & 52,3 & 50,9 & 49,7 & 52,8 & 142,3 & 58,7 & 81,2 \\
\hline $\begin{array}{l}\text { Темп росту, } \\
\text { пункти }\end{array}$ & $X$ & $X$ & 1,096 & 1,013 & 1,056 & 0,929 & 0,973 & 0,976 & 1,062 & $X$ & $X$ & $X$ \\
\hline
\end{tabular}

"Розраховано автором за даними Державної служби статистики України [4, с. 12];

** $\mathrm{PH}$ - раціональні норми; ${ }^{* * *}$ Цільові значення індикаторів за джерелом [2, с. 21].

За 2005-2017 рр. споживання молока й молочних продуктів на одну особу скоротилося на $11,3 \%$, склавши 88,7 \% від раціональної норми та 74,1\% від цільового значення індикатора на 2020 р. Водночас споживання плодів, ягід і винограду у 2017 р. порів- няно 32005 р. зросло на 42,3\%, досягнувши 58,7 \% раціональної норми та 58,7 \% від цільового показника 2020 р. Динаміка ланцюгових індексів свідчить про незначні зміни індикаторів протягом 2010-2017 рр. в Україні (див. табл. 2). У 2013 р. спостерігається най- 
більше зростання обсягів споживання продуктів харчування: м'яса і м'ясопродуктів - на $3,1 \%$, молока й молокопродуктів - на 2,8 \%, плодів і винограду - на $5,6 \%$. У наступні роки динаміка змін $є$ незначною.

В Україні доволі високою залишається частка витрат населення на продукти харчування. Так, у 2017 р. ця частка у сукупних споживчих витратах домогосподарств становила 47,9 \% [5], що у декілька разів перевищує аналогічний показник для європейських держав. Через низку купівельну спроможність українські споживачі віддають перевагу дешевим продуктам, по яких фактичне споживання досягає або перевищує науково обгрунтовані норми (у 2017 р. споживання картоплі склало $115 \%$ від раціональної норми, хлібних продуктів - 99,8 \%, овочів - 99,2 \% [4, с. 12]). Це є свідченням незадовільного стану продовольчої безпеки в Україні.

Позиція України в рейтингу за індексом глобальної продовольчої безпеки, починаючи з 2014 р., протягом останніх п'яти років знижується - країна займає 63 місце із загальним показником 55,7. Водночас слід зазначити зростання показників доступності та якості/безпеки продуктів харчування - 73 та 46 місця відповідно [6].

Для моніторингу досягнення другого завдання - подвійне зростання продуктивності сільського господарства - запропоновано групу індикаторів продуктивності праці в агросекторі та індексів сіль- ськогосподарської продукції (див. табл. 1). За статистичними даними, у 2017 р. показник продуктивності праці у сільськогосподарських підприємствах склав 271,5 тис. грн. / зайнятого (у постійних цінах 2010 р.), збільшившись порівняно 32005 р. у 3,7 рази [5]. Серед чинників, що визначають динаміку продуктивності праці, слід відзначити зменшення кількості зайнятих у сільському господарстві з 4 млн. осіб у 2005 р. до 2,86 млн. осіб у 2017 р. (на 28,6 \%) [7, с. 223]. Невисокий рівень продуктивності праці зумовлений зношеними основними засобами, низьким рівнем використання інноваційних технологій, нерозвиненістю інфраструктури сільських територій тощо. У 2015 р. продуктивність праці у сільськогосподарських підприємствах на одного працюючого склала 8,7 тис. дол. США, що складає 87 \% від цільового значення показника 2020 р. [2, с. 22].

У 2017 р. індекс сільськогосподарської продукції в Україні склав 97,8 \%, що менше на 0,8\% рівня 2010 р. та на 4,2 \% цільового значення індикатора (102\%). У тваринництві в 2017 р. за останні чотири роки вперше спостерігається позитивне значення індексу, у рослинництві наявна тенденція його $3 \%$-го скорочення (таблиця 3). За аналізований період 20102017 pр. найвище значення індексу виробництва продукції рослинництва спостерігалося в 2011 р., продукції тваринництва - в 2013 р.

Індекси сільськогосподарської продукції в Україні, \%

Таблиця 3

\begin{tabular}{|c|c|c|c|c|c|c|c|c|c|c|}
\hline \multirow[b]{2}{*}{ Показники } & \multicolumn{8}{|c|}{ Роки } & \multicolumn{2}{|c|}{$\begin{array}{l}\text { Відхилення } \\
2017 \text { p. }(+,-)\end{array}$} \\
\hline & 2010 & 2011 & 2012 & 2013 & 2014 & 2015 & 2016 & 2017 & $\begin{array}{c}\text { Від } \\
2010 \\
\text { року }\end{array}$ & $\begin{array}{c}\text { Від } \\
\text { Ц3 }{ }^{* * *} \\
(\mathbf{1 0 2 \%}) \\
\end{array}$ \\
\hline $\begin{array}{l}\text { 1.Індекс С } \Gamma^{* *} \text { продукції } \\
\text { за видами діяльності: } \\
\text { 1.1.Рослинництво }\end{array}$ & 95,9 & 130,7 & 92,6 & 118,0 & 103,2 & 94,8 & 109,9 & 97,0 & $+1,1$ & $-5,0$ \\
\hline 1.2.Тваринництво & 103,6 & 101,3 & 104,3 & 104,6 & 99,7 & 96,3 & 98,0 & 100,1 & $-3,5$ & $-1,9$ \\
\hline $\begin{array}{l}\text { 2.Індекс СГ продукції } \\
\text { за категоріями вироб- } \\
\text { ників, усього, в т.ч.: }\end{array}$ & 98,6 & 120,2 & 96,1 & 113,6 & 102,2 & 95,2 & 106,3 & 97,8 & $-0,8$ & $-4,2$ \\
\hline 2.1. СГ підприємства & 97,7 & 129,0 & 94,0 & 121,5 & 104,0 & 94,9 & 110,0 & 96,8 & $-0,9$ & $-5,2$ \\
\hline $\begin{array}{l}\text { у т.ч. фермерські гос- } \\
\text { подарства }\end{array}$ & н.д. & 134,6 & 88,1 & 135,9 & 101,5 & 98,6 & 116,9 & 98,4 & $\mathrm{X}$ & $-3,6$ \\
\hline $\begin{array}{l}\text { 2.2. Господарства насе- } \\
\text { лення }\end{array}$ & 99,4 & 111,9 & 98,4 & 105,5 & 99,9 & 95,7 & 101,8 & 99,2 & $-0,2$ & $-2,8$ \\
\hline
\end{tabular}

"За даними Державної служби статистики України $[8,9] ;{ }^{* *}$ СГ - сільськогосподарський;

**** ЦЗ - цільове значення.

Характерна для 2016 року тенденція зростання індексу сільськогосподарської продукції для усіх категорій виробників у 2017 році змінилася на протилежну (див. табл. 3). Порівняно з 2010 р. у звітному році в сільгосппідприємствах індекс скоротився на $0,9 \%$, у господарствах населення - на 0,2\%. Загалом за період 2010-2017 рр. динаміка індексу є нестабільною, варіативною. Якщо у 2011, 2013, 2016 його рівень перевищує цільовий орієнтир, то в інші роки він $\epsilon$ меншим даного орієнтиру і має негативне значення, сигналізуючи про скорочення обсягів випуску агропродукції. 
Моніторинг досягнення третього завдання забезпечення створення стійких систем виробництва продуктів харчування - проводиться за допомогою індексів виробництва харчових продуктів та групи показників органічного землеробства (див. табл. 1). У 2017 р. індекс виробництва харчових продуктів в
Україні склав 102,9 \%, майже досягнувши цільового значення показника в $103 \%$ (таблиця 4). Порівняно 3 2010 р. індекс скоротився на 0,8 \%. У 2014-2017 pp. має місце певна кореляція між індексами сільськогосподарської та харчової продукції, що наочно відображено на рис. 2.

Таблиця 4

Індекси виробництва та частка експорту харчових продуктів в експорті товарних груп 1-24 УКТЗЕД, \%*

\begin{tabular}{|c|c|c|c|c|c|c|c|c|c|c|c|}
\hline \multirow{2}{*}{ Показники } & \multicolumn{8}{|c|}{ Роки } & \multirow{2}{*}{ Ц3 ${ }^{* *}$} & \multicolumn{2}{|c|}{$\begin{array}{l}\text { Відхилення } \\
2017 \text { p. }(+,-)\end{array}$} \\
\hline & 2010 & 2011 & 2012 & 2013 & 2014 & 2015 & 2016 & 2017 & & $\begin{array}{c}\text { Від } \\
2010\end{array}$ & $\begin{array}{l}\text { Від } \\
\text { Ц3 }\end{array}$ \\
\hline $\begin{array}{l}\text { 1. Індекс виро- } \\
\text { бництва харчо- } \\
\text { вих продуктів }\end{array}$ & 103,7 & 99,4 & 101,0 & 94,9 & 102,5 & 89,3 & 104,4 & 102,9 & 103 & $-0,8$ & $-0,1$ \\
\hline $\begin{array}{l}\text { 2. Частка про- } \\
\text { дукції харчової } \\
\text { промисловості } \\
\text { та переробки } \\
\text { СГсировини в } \\
\text { експорті груп } \\
\text { 1-24 УКТЗЕД }\end{array}$ & 52,2 & 49,5 & 43,1 & 41,5 & 41,5 & 39,6 & 42,0 & 41,9 & 51 & $-10,3$ & $-9,1$ \\
\hline
\end{tabular}

"За даними Державної служби статистики України [5; 8,с.262; 9, с. 23];

** Ц3 - цільове значення показників за джерелом [2, с. 21].

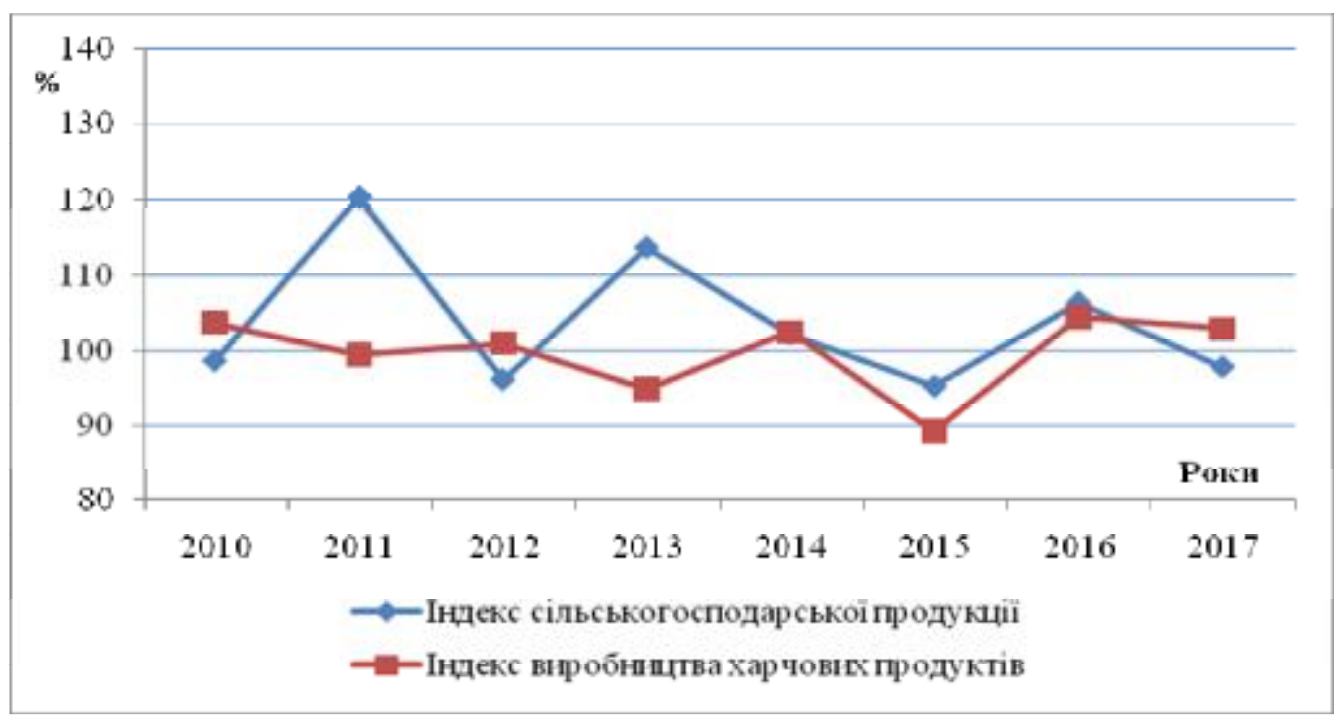

Рис. 2. Динаміка індексів сільськогосподарської та харчової продукції в Україні* *Побудовано за даними таблиць 3,4.

Частка продукції харчової промисловості та переробки сільськогосподарської сировини в експорті товарних груп 1-24 УКТЗЕД склала у 2017 р. 41,9 \%, що на 9,1\% нижче цільового значення показника (див. табл. 4). За 2013-2017 рр. рівень індикатора був відносно стабільним і варіював у межах 41-42 \%.

У 2017 р. загальна площа сертифікованих сільськогосподарських угідь в Україні, зайнятих під вирощування різноманітної органічної продукції, досягла 420 тис. га, збільшившись порівняно з 2005 р. на 73,6\% (таблиця 5). За цим показником Україна займає 20 місце серед світових держав-лідерів органі- чного руху [10]. За 2005-2017 pр. найвищий темп приросту (44,2 \%) спостерігався в 2013 р. За період 2014-2017 pр. щорічні темпи зростання обсягів органічних угідь сповільнилися і варіювали в межах 1,9$2,1 \%$.

Незважаючи на стрімкі темпи зростання, частка органічних угідь у загальній площі сільськогосподарських угідь України в 2017 р. склала всього $1,01 \%$, що на 0,09\% нижче цільового значення індикатора (1,1 \% в 2020 р.). Позитивною є стійка тенденція до зростання як площ органічних угідь, так і їх частки у загальній площі угідь з 0,58 \% в 2005p. до 
$1,01 \%$ в 2017 р. (на 0,43 \%). Питома вага органічних земель у загальній території держави досягла в звітному році 0,70\%, збільшившись порівняно з 2005 р. на $0,3 \%$. За аналізований період кількість органічних господарств зросла в 5,2 рази і склала в 2017 р. 375 одиниць. Темп росту кількості органічних виробників перевищує темп росту площ органічних сільськогосподарських угідь (див. табл. 5).

Таблиця 5

Динаміка площ органічних сільськогосподарських угідь та кількості органічних господарств в Україні*

\begin{tabular}{|c|c|c|c|c|c|c|c|c|c|c|}
\hline \multirow{2}{*}{ Показники } & \multicolumn{9}{|c|}{ Роки } & \multirow{2}{*}{$\begin{array}{c}2017 \mathrm{p} . \mathrm{y} \\
\% \text { до } \\
2005 \mathrm{p} .\end{array}$} \\
\hline & 2005 & 2010 & 2011 & 2012 & 2013 & 2014 & 2015 & 2016 & 2017 & \\
\hline 1. Площа, тис. га & 242,0 & 270,2 & 270,3 & 272,9 & 393,4 & 400,8 & 410,6 & 411,2 & 420,0 & 173,6 \\
\hline Темп росту, пункти & $X$ & $X$ & 1,000 & 1,009 & 1,442 & 1,019 & 1,024 & 1,002 & 1,021 & $\mathrm{X}$ \\
\hline $\begin{array}{l}\text { 2. Частка органічних } \\
\text { угідь у загальній площі } \\
\text { СГ угідь,\% }\end{array}$ & 0,58 & 0,65 & 0,65 & 0,66 & 0,95 & 0,97 & 0,99 & 0,99 & 1,01 & $\begin{array}{c}(+,-) \\
+0,43\end{array}$ \\
\hline $\begin{array}{l}\text { 3. Частка органічних } \\
\text { угідь у загальній тери- } \\
\text { торії країни, \% }\end{array}$ & 0,40 & 0,45 & 0,45 & 0,45 & 0,65 & 0,66 & 0,68 & 0,68 & 0,70 & $\begin{array}{c}(+,-) \\
+0,30\end{array}$ \\
\hline $\begin{array}{l}\text { 4. Кількість органічних } \\
\text { господарств, одиниць }\end{array}$ & 72 & 142 & 155 & 164 & 175 & 182 & 210 & 330 & 375 & 520,8 \\
\hline Темп росту, пункти & $\mathrm{X}$ & $X$ & 1,092 & 1,058 & 1,067 & 1,040 & 1,154 & 1,571 & 1,136 & $\mathrm{X}$ \\
\hline
\end{tabular}

* Розраховано автором за даними Федерації органічного руху в Україні [10]

Україна посідає перше місце серед країн Східної Європи за площею органічних орних земель, спеціалізуючись переважно на виробництві зернових, зернобобових і олійних культур. Дослідження Федерації органічного руху України свідчать, що вітчизняний ринок органічної продукції почав розвиватися 3 початку 2000-х років, склавши: у 2005 р. - 200 тис. євро, у 2010 р. - 2,4 млн. євро, у 2017 р. - 29,4 млн. євро. Більшість українських органічних господарств знаходиться в Одеській, Херсонській, Київській, Полтавській, Вінницькій, Закарпатській, Львівській, Тернопільській, Житомирській областях. Українські сертифіковані органічні господарства різного розміру від кількох гектарів, як у більшості країн Свропи, до декількох тисяч гектарів ріллі [10].

Динаміка обсягів внесення мінеральних добрив аграрними підприємствами України (таблиця 6) має зростаючий тренд. Так, у 2017 р. під посіви сільськогосподарських культур виробниками було внесено 2023,8 тис. т мінеральних добрив, що у 3,6 рази вище показника 2005 року. В Україні обсяги внесених мінеральних добрив на 1 га посівної площі зросли 3 32 кг в 2005 р. до 110 кг в 2017 р., тобто в 3,4 рази, на 1 га удобреної площі - в 1,7 рази. У 2017 р. обсяги внесених агропідприємствами мінеральних добрив досягли близько 80 \% від світового показника. Українські виробники віддають перевагу швидкодіючим азотним добривам. У 2017 р. частка азотних добрив склала 67,3 \%, фосфорних - 17,9 \%, калійних - 14,8 \% [7]. За дослідженнями учених, мають місце структурні диспропорції у співвідношенні основних елементів живлення у внесених мінеральних добривах із значним переважанням у них частки азотних. Так, у
1990 р. дане співвідношення становило 1:0,8:0,9, а в 2014-му - 1:0,2:0,3, що є досить небезпечним явищем з екологічного погляду [12, с. 23].

Незважаючи на стійку тенденцію щорічного зростання внесених мінеральних добрив, обсяги використаних органічних добрив у сільському господарстві України щорічно знижуються (див. табл. 6). Так, у 2017 р. під урожай звітного року було внесено 9274 тис. т органічних добрив, що на 30,7 \% менше показника 2005 року. Під посіви сільськогосподарських культур у 2017 р. агропідприємствами було внесено 9250 тис. т добрив, що на 30,2\% менше рівня 2005 р., водночас на 1,3\% вище рівня 2016 року. Після щорічного зниження (2-5\%) обсягів внесених органічних добрив у 2015-2016 pp. у звітному періоді спостерігається незначне $1 \%$-ве зростання.

За досліджуваний період розмір удобреної площі практично не змінився і складав 0,4-0,5 млн. га. Частка удобреної площі скоротилася з 3,0\% в 2005 р. до 2,7\% в 2017 р. У 2017 р. на 1 га посівної площі було внесено 0,5 кг. органічних добрив, що на 37,5 \% менше показника 2005 р. (див. табл. 6). Органічні добрива відіграють важливу роль у збереженні, відтворенні та підвищенні родючості грунтів. Основною умовою поліпшення ситуації $є$ посилення уваги до розвитку тваринництва, кількісного нарощування поголів'я тварин [12, с. 25].

Грунти та їх стан $є$ основною і найбільш потужною компонентою навколишнього середовища, одним з головних чинників забезпечення продовольчої безпеки держави та основи життя. У сільському господарстві продуктивність виробництва значною мірою залежить від стану грунтового покриву. 
Таблиця 6

Внесення мінеральних та органічних добрив у сільськогосподарських підприсмствах України"

\begin{tabular}{|c|c|c|c|c|c|c|c|c|c|c|c|}
\hline \multirow{2}{*}{ Показники } & \multicolumn{9}{|c|}{ Роки } & \multicolumn{2}{|c|}{$\begin{array}{c}2017 \text { p. y \% } \\
\text { до: } \\
\end{array}$} \\
\hline & 2005 & 2010 & 2011 & 2012 & 2013 & 2014 & 2015 & 2016 & 2017 & 2005 & 2016 \\
\hline \multicolumn{12}{|c|}{ Мінеральні добрива } \\
\hline $\begin{array}{l}\text { 1. Внесено під посіви } \\
\text { с/Г культур, тис. т }\end{array}$ & 558 & 1061 & 1263 & 1343 & 1490 & 1469 & 1412 & 1724 & 2024 & $\begin{array}{c}362 \\
8\end{array}$ & $\begin{array}{c}117 \\
4\end{array}$ \\
\hline Темп росту, пункти & $\mathrm{X}$ & $\mathrm{X}$ & 1,191 & 1,063 & 1,109 & 0,986 & 0,961 & 1,221 & 1,174 & $\mathrm{X}$ & $\mathrm{X}$ \\
\hline $\begin{array}{l}\text { 2.Удобрена площа, млн. } \\
\text { га }\end{array}$ & 7,8 & 12,6 & 14,2 & 14,6 & 15,3 & 14,7 & 14,5 & 15,6 & 16,5 & 211,5 & 105,8 \\
\hline Темп росту, пункти & X & $\mathrm{X}$ & 1,127 & 1,028 & 1,048 & 0,961 & 0,986 & 1,076 & 1,058 & $\mathrm{X}$ & $\mathrm{X}$ \\
\hline $\begin{array}{l}\text { 3.Частка удобреної } \\
\text { площі, \% }\end{array}$ & 45 & 70 & 76 & 78 & 81 & 82 & 81 & 87 & 89 & $\mathrm{X}$ & $\mathrm{X}$ \\
\hline $\begin{array}{l}\text { 4.Внесено на } 1 \text { га посі- } \\
\text { вної площі, кг }\end{array}$ & 32 & 58 & 68 & 72 & 79 & 82 & 79 & 96 & 110 & 343,8 & 114,6 \\
\hline \multicolumn{12}{|c|}{ Органічні добрива } \\
\hline $\begin{array}{l}\text { 1.Внесено під посіви с/г } \\
\text { культур, тис. т }\end{array}$ & 13246 & 9874 & 9846 & 9637 & 9603 & 9861 & 9636 & 9133 & 9250 & 69,8 & 101,3 \\
\hline Темп росту, пункти & $\mathrm{X}$ & $\mathrm{X}$ & 0,997 & 0,979 & 0,996 & 1,027 & 0,977 & 0,948 & 1,013 & $X$ & $X$ \\
\hline $\begin{array}{l}\text { 2.Удобрена площа, млн. } \\
\text { га }\end{array}$ & 0,5 & 0,4 & 0,4 & 0,4 & 0,4 & 0,4 & 0,4 & 0,5 & 0,5 & 100 & 100 \\
\hline $\begin{array}{l}\text { 3.Частка удобреної } \\
\text { площі, \% }\end{array}$ & 3,0 & 2,0 & 2,0 & 2,0 & 2,0 & 2,0 & 2,5 & 2,6 & 2,7 & X & $\mathrm{X}$ \\
\hline $\begin{array}{l}\text { 4.Внесено на } 1 \text { га посі- } \\
\text { вної площі, кг }\end{array}$ & 0,8 & 0,5 & 0,5 & 0,5 & 0,5 & 0,5 & 0,5 & 0,5 & 0,5 & 62,5 & 100 \\
\hline
\end{tabular}

* Розраховано автором за даними Державної служби статистики України [7, с. 128; 6,с.319].

Баланс гумусу в грунтах України вказує на тенденцію зменшення запасів гумусу за період 20002010 pр. У 2011 р. рівень втрат гумусу скоротився до -0,37 т/га, у 2013 р. - до -0,13 т/га. Однією з основних причин такого стану $є$ значне зменшення внесення органічних добрив. Період 2011-2013 рр. визначається тенденцією зменшення втрат гумусу, водночас показник запасів гумусу в грунтах не досягнув позитивного значення. Баланс поживних речовин в грунтах України досяг мінімального значення у 20012005 pр. (-136 кг/га) та зріс у 2011-2012 рр. (-89 кг/га), однак не досягнув позитивного значення [13, с. 106107].

В Україні відбувається збіднення грунтів на вміст таких важливих поживних речовин для формування врожаю, як рухомий фосфор і калій. Через надмірну розораність, дефіцитний баланс гумусу i поживних речовин, недостатнє внесення органічних речовин та мінеральних добрив, забруднення, грунти України в сучасних умовах продовжують деградувати [13, с. 107].

Досягнення четвертого завдання - зниження волатильності цін на продукти харчування - передбачає аналіз індексів споживчих цін на продукти харчування (див. табл. 1). У 2017 р. індекс споживчих цін для продуктів харчування склав 118,3 \%, що на 7,5\% вище рівня 2005 р. і на 13,3\% вище цільового значення показника (таблиця 7). У звітному році найвищий рівень індексу споживчих цін спостерігався за такими товарними групами, як фрукти $(134,5 \%)$, м'ясо й м'ясопродукти, $(129,4 \%)$, овочі $(124,7 \%)$, найнижчий - цукор $(92,6 \%)$, риба та продукти з риби $(100,5 \%)$.

Таблиця 7

Індекси споживчих цін на продукти харчування в Україні, грудень до грудня попереднього року, $\%^{*}$

\begin{tabular}{|c|c|c|c|c|c|c|c|c|c|c|c|}
\hline \multirow{2}{*}{ Товари } & \multicolumn{9}{|c|}{ Роки } & \multicolumn{2}{|c|}{$\begin{array}{c}\text { Відхилення } \\
2017 \mathrm{p.} \mathrm{(+,-)}\end{array}$} \\
\cline { 2 - 11 } & 2005 & 2010 & 2011 & 2012 & 2013 & 2014 & 2015 & 2016 & 2017 & $\begin{array}{c}\text { Від } \\
2005 p\end{array}$ & $\begin{array}{c}\text { Від } \\
\text { Ц3 } \\
\mathbf{1 0 5 \%}\end{array}$ \\
\hline $\begin{array}{l}\text { 1.Продукти хар- } \\
\text { чування, всього, } \\
\text { у т.ч. }\end{array}$ & $\mathbf{1 1 0 , 8}$ & $\mathbf{1 1 0 , 7}$ & $\mathbf{1 0 0 , 7}$ & $\mathbf{9 7 , 1}$ & $\mathbf{9 9 , 2}$ & $\mathbf{1 2 4 , 5}$ & $\mathbf{1 4 0 , 1}$ & $\mathbf{1 0 3 , 2}$ & $\mathbf{1 1 8 , 3}$ & $\mathbf{7 , 5}$ & $\mathbf{1 3 , 3}$ \\
\hline
\end{tabular}


Продовження табл.7

\begin{tabular}{|c|c|c|c|c|c|c|c|c|c|c|c|}
\hline \multirow[b]{2}{*}{ Товари } & \multicolumn{9}{|c|}{ Роки } & \multicolumn{2}{|c|}{$\begin{array}{l}\text { Відхилення } \\
\text { 2017p. }(+,-) \\
\end{array}$} \\
\hline & 2005 & 2010 & 2011 & 2012 & 2013 & 2014 & 2015 & 2016 & 2017 & $\begin{array}{c}\text { Від } \\
2005 p\end{array}$ & $\begin{array}{c}\text { Від } \\
\text { Ц3 } \\
\mathbf{1 0 5 \%}\end{array}$ \\
\hline $\begin{array}{l}\text { 2.Хліб і хлібоп- } \\
\text { родукти }\end{array}$ & 102,2 & 116,5 & 106,3 & 99,7 & 100,3 & 135,1 & 144,6 & 106,3 & 110,7 & 8,5 & 5,7 \\
\hline $\begin{array}{l}\text { 3.М'ясо та } \\
\text { м'ясопродукти }\end{array}$ & 118,4 & 104,1 & 109,8 & 101,3 & 96,9 & 127,5 & 122,5 & 105,0 & 129,4 & 11 & 24,4 \\
\hline $\begin{array}{l}\text { 4.Риба та проду- } \\
\text { кти з риби }\end{array}$ & 119,4 & 104,2 & 109,9 & 98,3 & 96,5 & 137,2 & 142,4 & 102,4 & 100,5 & $-18,9$ & $-4,5$ \\
\hline $\begin{array}{l}\text { 5.Молоко, сир та } \\
\text { яйця }\end{array}$ & 110,1 & 116,0 & 106,0 & 93,4 & 106,2 & 117,2 & 133,5 & 113,1 & 121,6 & 11,5 & 16,6 \\
\hline 6.Олія та жири & 102 & 108,1 & 106,7 & 99,2 & 98 & 121,1 & 141,5 & 110,3 & 119,6 & 17,6 & 14,6 \\
\hline 7.Фрукти & 126,1 & 109,3 & 96,4 & 97,9 & 82,6 & 155,9 & 148,2 & 93,5 & 134,5 & 8,4 & 29,5 \\
\hline 8.Овочі & 104,7 & 120,9 & 55,9 & 77,5 & 105,8 & 89,4 & 166,7 & 71,4 & 124,7 & 20 & 19,7 \\
\hline 9.Цукор & 121,7 & 120,3 & 79,5 & 83,2 & 118,0 & 122,8 & 169,8 & 98,8 & 92,6 & $-29,1$ & $-12,4$ \\
\hline
\end{tabular}

"За даними Державної служби статистики України [9,c.101; 11, с. 63];

*** Ц3 - цільове значення показників за джерелом [2, с. 21].

За досліджуваний період рівень варіації індексу споживчих цін продуктів харчування $\epsilon$ досить високим, особливо для фруктів. Цінова ситуація на продовольчому ринку України значною мірою визначалася знеціненням національної грошової одиниці протягом 2014-2015 рр. У зв'язку з цим індекси споживчих цін продуктів харчування істотно зросли в 2015 р. за всіма товарними групами. Найвищі рівні індексу споживчих цін у 2015 р. були характерні для цукру (169,8 \%), овочів (166,7 \%), фруктів (148,2 \%); середнє значення показника для продуктів харчування склало 140,1 \% (див. табл. 7). Обмеження надмір- ної волатильності цін на продукти харчування $є$ одним із важливих завдань держави на шляху досягнення другої Цілі сталого розвитку.

Результати проведеного аналізу рівнів і напрямів зміни індикаторів досягнення другої Цілі сталого розвитку дозволяють визначити загальну динаміку змін (зростання, зменшення) основних показників за 2005-2017 рр. в Україні та надати якісну оцінку таким змінам. Якісна оцінка напряму і характеру змін індикаторів досягнення другої ЦСР представлена в таблиці 8.

Якісна оцінка динаміка змін індикаторів досягнення другої ЦСР*

\begin{tabular}{|c|c|c|}
\hline Показники & $\begin{array}{c}\text { Динаміка змін: } \\
\text { зростання } \uparrow \\
\text { зменшення } \downarrow\end{array}$ & $\begin{array}{c}\text { Оцінка динаміки: } \\
\text { П; Н; БЗ; ЦНД; } \\
\text { ДД }\end{array}$ \\
\hline 1 & 2 & 3 \\
\hline \multicolumn{3}{|c|}{$\begin{array}{l}\text { 2.1. Забезпечити доступність збалансованого харчування на рівні науково обгрунтованих норм для всіх } \\
\text { верств населення }\end{array}$} \\
\hline 2.1.1. Споживання м’яса в розрахунку на одну особу, кг/рік & $\uparrow$ & П, ДД \\
\hline 2.1.2. Споживання молока в розрахунку на одну особу, кг/рік & $\downarrow$ & $\mathrm{H}$ \\
\hline 2.1.3. Споживання фруктів в розрахунку на одну особу, кг/рік & $\uparrow$ & П, ДД \\
\hline $\begin{array}{l}\text { 2.1.4. Індекси споживання м’яса, молока та фруктів на одну особу; } \\
\text { у \% раціональної норми, цільового показника } 2020 \text { р. }\end{array}$ & $\uparrow ; \downarrow ; \uparrow$ & ЦНД \\
\hline \multicolumn{3}{|c|}{$\begin{array}{l}\text { 2.2. Підвищити вдвічі продуктивність сільського господарства, насамперед за рахунок використання ін- } \\
\text { новаційних технологій }\end{array}$} \\
\hline $\begin{array}{l}\text { 2.2.1. Продуктивність праці в сільському господарстві на одного } \\
\text { зайнятого }\end{array}$ & $\uparrow$ & П; ДД \\
\hline 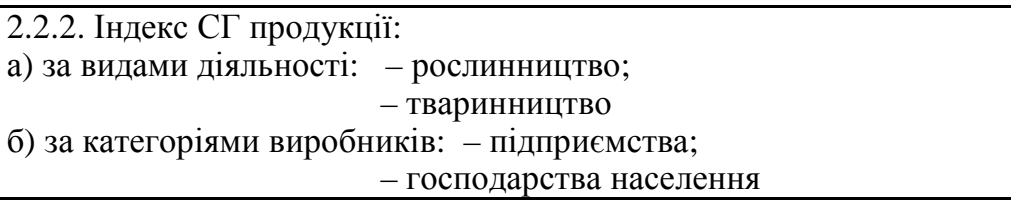 & $\begin{array}{l}\uparrow \\
\downarrow \\
\downarrow \\
\downarrow\end{array}$ & $\begin{array}{l}\Pi \\
\mathrm{H} \\
\mathrm{H} \\
\mathrm{H} \\
\end{array}$ \\
\hline $\begin{array}{l}\text { 2.2.3. Індекс продуктивності праці в сільському господарстві на } \\
\text { одного зайнятого, у \% до } 2005 \text { р. }\end{array}$ & $\uparrow$ & П; ДД \\
\hline $\begin{array}{l}\text { 2.2.4.Динаміка індексу сільськогосподарської продукції (+, - порів- } \\
\text { няно } 3 \text { цільовим показником } 2020 \text { р.) }\end{array}$ & $\downarrow$ & ЦНД \\
\hline
\end{tabular}


Продовження табл. 8

\begin{tabular}{|c|c|c|}
\hline Показники & $\begin{array}{c}\text { Динаміка змін: } \\
\text { зростання } \uparrow \\
\text { зменшення } \downarrow\end{array}$ & $\begin{array}{l}\text { Оцінка динаміки: } \\
\text { П; Н; БЗ; ЦНД; } \\
\text { ДД }^{* *}\end{array}$ \\
\hline 1 & 2 & 3 \\
\hline \multicolumn{3}{|c|}{$\begin{array}{c}\text { 2.3.Забезпечити створення стійких систем виробництва продуктів харчування, шео сприяють збережен- } \\
\text { но екосистем і поступово покрацуоть якість земель та трунтів, насамперед за рахунок використання } \\
\text { інноваційних технологій }\end{array}$} \\
\hline 2.3.1. Індекс виробництва харчових продуктів, \% & $\downarrow$ & $\mathrm{H}$ \\
\hline $\begin{array}{l}\text { 2.3.2.Частка продукції харчової промисловості та переробки аграр- } \\
\text { ної сировини в експорті груп 1-24 УКТЗЕД, \% }\end{array}$ & $\downarrow$ & $\mathrm{H}$ \\
\hline $\begin{array}{l}\text { 2.3.3. Частка органічних сільськогосподарських угідь у загальній } \\
\text { площі сільськогосподарських угідь }\end{array}$ & $\uparrow$ & $\Pi$ \\
\hline $\begin{array}{l}\text { 2.3.4. Динаміка індексу виробництва харчових продуктів (+, - порі- } \\
\text { вняно з цільовим показником } 2020 \text { р.) }\end{array}$ & $\uparrow$ & $\Pi$ \\
\hline $\begin{array}{l}\text { 2.3.5. Динаміка частки продукції харчової промисловості в експор- } \\
\text { ту груп 1-24 УКТЗЕД (+, - порівняно з цільовим показником } \\
2020 \text { р.) }\end{array}$ & $\downarrow$ & ЦНД \\
\hline $\begin{array}{l}\text { 2.3.6. Частка органічних сільськогосподарських угідь у загальній } \\
\text { території країни, \% }\end{array}$ & $\uparrow$ & $\Pi$ \\
\hline $\begin{array}{l}\text { 2.3.7.Індекс площ органічних сільськогосподарських угідь, \% до } \\
2005 \text { р. }\end{array}$ & $\uparrow$ & $\Pi$ \\
\hline 2.3.8.Індекс кількості органічних господарств в Україні \% до 2005р. & $\uparrow$ & $\Pi$ \\
\hline $\begin{array}{l}\text { 2.3.9. Динаміка частки органічних угідь у загальній площі с/г угідь } \\
(+,- \text { порівняно з цільовим показником } 2020 \text { р.) }\end{array}$ & $\uparrow$ & ЦНД \\
\hline $\begin{array}{l}\text { 2.3.10. Динаміка частки органічних угідь у загальній території краї- } \\
\text { ни (+, - порівняно з } 2005 \text { р.) }\end{array}$ & $\uparrow$ & $\Pi$ \\
\hline $\begin{array}{l}\text { 2.3.13. Обсяг внесених добрив (мінеральних і органічних) СГП }{ }^{* * * *} \text { на } \\
1 \text { га посівної площі, кг/га: а) мінеральних; } \\
\text { б) органічних. }\end{array}$ & $\uparrow$ & $\begin{array}{l}\Pi \\
\text { Б3 }\end{array}$ \\
\hline $\begin{array}{l}\text { 2.3.14. Індекс внесених добрив СГП на } 1 \text { га посівної площі, \% до } \\
2005 \text { р: а) мінеральних; } \\
\text { б) органічних. }\end{array}$ & $\uparrow$ & $\begin{array}{l}\Pi \\
\mathrm{H}\end{array}$ \\
\hline $\begin{array}{l}\text { 2.3.15. Індекс внесених добрив (у видовому розрізі) СГП під уро- } \\
\text { жай звітного року, \% до } 2005 \text { р.: } \\
\text { а) мінеральних (азотні, фосфорні, калійні); } \\
\text { б) органічних. }\end{array}$ & $\uparrow$ & $\begin{array}{l}\Pi \\
\mathrm{H}\end{array}$ \\
\hline $\begin{array}{l}\text { 2.3.16. Зміна структури внесених мінеральних добрив СГП, \% (+, - } \\
\text { порівняно } 32005 \text { р.) }\end{array}$ & - & $\Pi$ \\
\hline 2.3.17. Внесення азотних та фосфорних добрив, т/1000 га & $\uparrow$ & П, ЦНД \\
\hline 2.3.18. Баланс гумусу в грунтах України, т/га & $\downarrow$ & ЦНД \\
\hline 2.3.19. Баланс поживних речовин в грунтах України, т/га & $\downarrow$ & ЦНД \\
\hline \multicolumn{3}{|c|}{ 2.4. Знизити волатильність цін на продукти харчування } \\
\hline $\begin{array}{l}\text { 2.4.1. Індекс споживчих цін на продукти харчування (середньоріч- } \\
\text { ний) за основними групами продуктів, \% }\end{array}$ & $\uparrow$ & $\mathrm{H}$ \\
\hline $\begin{array}{l}\text { 2.4.2. Динаміка індексу споживчих цін на продукти харчування (+, } \\
\text { - порівняно з иілььовим показником } 2020 \text { р.) }\end{array}$ & $\uparrow$ & ЦНД \\
\hline
\end{tabular}

"Складено автором на підставі даних таблиць 2-7;

** Умовні позначення: П - позитивна динаміка; Н - негативна; БЗ - без значних змін; ЦНД - цільове значення показника не досягнуто; ДД - оцінка потребує додаткових досліджень;

${ }^{* * *}$ СГП - сільськогосподарські підприємства.

Незважаючи на позитивну тенденцію зростання рівня споживання м'ясних продуктів і фруктів у розрахунку на одну особу за період 2005-2017 pp., динаміка зміни групи індикаторів забезпечення доступності збалансованого харчування для усіх верств населення залишається незадовільною (див. табл. 8). Фактичні рівні споживання м'ясних і молочних продуктів, а також фруктів в Україні є значно нижчими раціональних норм споживання і цільових значень показників 2020 р., генеруючи потенційні загрози національній продовольчій безпеці.

Тенденція зростання показника продуктивності праці одного зайнятого в сільськогосподарських підприємствах (у постійних цінах 2010 р.) за період 2005-2017 рр. супроводжується зменшенням кількості зайнятих у сільському господарстві Україні та низьким рівнем використання інноваційних технологій. За 2010-2017 рр. індекс сільськогосподарської продукції за категоріями виробників та видом діяльності «тваринництво» має знижувальний тренд, зростаюча ди- 
наміка показника характерна для рослинництва (див. табл. 8). Водночас за досліджуваний період індекс сільськогосподарської продукції не досягнув цільового значення індикатора 2020 року.

Незважаючи на зниження індексу виробництва харчових продуктів у 2017 р. порівняно з 2010 р., у звітному році його значення практично досягнуло цільового показника, що є позитивною тенденцію. Частка продукції харчової й переробної промисловості в експорті груп 1-24 УКТЗЕД має потенціал зростання до цільового значення показника 2020 р.

Динаміка змін групи індикаторів органічного виробництва в Україні за 2005-2017 рр. є стабільно позитивною, має зростаючий тренд, свідчить про зростання частки органічних угідь у загальній площі сільськогосподарських угідь та загальній території країни, збільшення індексу кількості органічних господарств в Україні (див. табл. 8). Водночас у звітному році індикатор частки органічних угідь у загальній площі сільськогосподарських угідь не досягнув цільового значення показника 2020 р.

Динаміка групи індикаторів обсягу внесених мінеральних добрив сільськогосподарськими підприємствами є позитивною та перманентно зростаючою. Водночас індикатор обсягу внесених мінеральних добрив на 1 га посівної площі в Україні складає близько 80 \% від світового показника. Мають місце структурні диспропорції у складі мінеральних добрив зі значним переважанням азотних добрив. Динаміка індикатора внесення азотних та фосфорних добрив в Україні $\epsilon$ позитивною, водночас його значення не досягло рівня індикатора провідних аграрних держав. Щоб використання мінеральних добрив у сільському господарстві відповідало вимогам сучасного землеробства, доцільно забезпечити ефективність їх виробництва із вітчизняної сировинної бази фосфоритів i калійних руд, що сприятиме зниженню собівартості добрив. Також необхідним є збільшення обсягів використання рідких і комплексних мінеральних добрив шляхом створення промислової технології виробництва, зберігання, транспортування та внесення їх у грунт [11, с. 27].

Динаміка групи індикаторів обсягу внесених органічних добрив сільськогосподарськими підприємствами України є негативною та знижувальною (див. табл. 8). Індикатор обсягу внесених органічних добрив на 1 га посівної площі за 2010-2017 рр. залишався незмінним. Значне зменшення внесення органічних добрив є однією з головних причин від'ємного балансу гумусу в Україні. Незважаючи на сповільнення втрат гумусу в грунтах України за період 20112013 рр., баланс не досягнув позитивного значення. Баланс поживних речовин в грунтах України теж має від'ємне значення. Для поповнення запасів органічної речовини в грунтах доцільно використовувати альтернативні джерела збільшенням питомої ваги багаторічних трав, зернових колосових і бобових культур у сівозмінах, розширенням посівів сидератів.

Динаміка індексів споживчих цін основних груп продовольчих товарів характеризується значним рівнем варіативності, має за 2005-2017 рр. зростаючий тренд, що є негативною тенденцією, та не досягає цільового значення показника 2020 року (див. табл. 8). Вирі- шення завдання зниження волатильності цін на продукти харчування знаходиться у площині реалізації виваженої державної агропродовольчої політики.

Висновки та перспективи подальших досліджень. Розроблений автором методологічний підхід до моніторингу індикаторів «зеленого» зростання об'єднав концептуальний базис як сукупність цілей, завдань і принципів моніторингу та методичний базис як сукупність методичних положень моніторингу індикаторів у розрізі восьми ЦСР та механізмів регулювання розвитку «зеленої» трансформації. У дослідженні запропоновано розширену систему індикаторів для оцінки досягнення другої ЦСР «Подолання голоду, розвиток сільського господарства» 3 акцентом на групи показників органічного землеробства, використання добрив, стану грунтів.

Проведений на базі даної системи індикаторів моніторинг їх стану й динаміки в Україні за 20052017 pр. показав, що у більшості випадків спостерігається негативна тенденція зниження основних показників, рівень яких є нижчим цільового значення індикаторів 2020 р., обгрунтованих Міністерством економічного розвитку і торгівлі України [2, с. 21]. Виняток складає група індикаторів органічного землеробства, динаміка яких за аналізований період має стійкий зростаючий тренд. Ця група індикаторів має значний потенціал зростання та досягнення цільових орієнтирів сталого розвитку. Розвитку вітчизняного ринку органічної продукції сприятиме вдосконалення інституційного середовища та впровадження механізмів стимулювання внутрішнього попиту на органічні товари, формування системи державних «зелених» закупівель. Також значний потенціал зростання мають показники індексу виробництва харчових продуктів та іiі частки в експорті груп 1-24 УКТЗЕД (див. табл. 1). Реалізації даного потенціалу покликана сприяти оновлена агропродовольча політика держави, яка змістить пріоритети з підтримки трейдерів до підтримки виробників і експортерів харчових продуктів 3 високою доданою вартістю, використовуючи світовий досвід.

Наукова новизна проведеного дослідження полягає в удосконаленні методичного забезпечення моніторингу індикаторів «зеленого» зростання на засадах сталого розвитку, яке базується на множині наукових принципів, розширеній оціночній основі 3 використанням оновленої системи прикладних економіко-екологічних показників, що всебічно охоплюють характеристики процесу «зеленої» трансформації національної економіки та орієнтовані на механізми регулювання ii розвитку. Прикладне значення отриманих результатів визначається можливістю їх використання державними органами влади в ході моніторингу прогресу «зеленого» зростання, обгрунтування стратегічних напрямів і заходів його стимулювання в країні, вдосконалення інституційного середовища. Перспективи подальших досліджень полягають у розширенні системи базових індикаторів ЦСР в Україні, розвитку методик їх моніторингу, а також їх апробації для підтвердження емпіричної результативності з використанням наукового підходу, висвітленого в даній статті. 


\title{
Література
}

1. Доповідь про зелену трансформацію в Україні на основі показників зеленого зростання ОЕСР. Міністерство економічного розвитку і торгівлі України, 2016. 60 с.

2. Цілі Сталого Розвитку: Україна: Національна доповідь 2017. Міністерство економічного розвитку і торгівлі України, 2017. 176 с.

3. Цілі сталого розвитку для України: регіональний вимір: аналітична доповідь. ДУ «Інститут регіональних досліджень ім. М.І. Долішнього НАН України». Львів, 2018. 90 с.

4. Баланси та споживання основних продуктів харчування населенням України: статистичний збірник / відп. за вип. О. М. Прокопенко. К.: Державна служба статистики України, 2018. 59 с.

5. Офіційний сайт Державної служби статистики України. URL: http://www.ukrstat.gov.ua/ (дата звернення 01.11.2018).

6. Офіційний сайт журналу «Пропозиція». URL: https://propozitsiya.com/ua/opublikovano-globalnyy-indeksprodovolchoyi-bezpeky-za-2018-rik (дата звернення 01.11.2018).

7. Сільське господарство України у 2017 році: статистичний збірник / відп. за випуск О. М. Прокопенко. К.: Державна служба статистики України, 2018. 245 с.

8. Статистичний щорічник України за 2016 рік / за ред. I. Є. Вернера. Київ: Державна служба статистики України, 2017. 610 с.

9. Україна у цифрах 2017: статистичний збірник / за ред. І. Є. Вернера. Київ: Державна служба статистики України, 2018. 241 с.

10. Офіційний сайт Федерації органічного руху в Україні: Органік в Україні. URL: http://organic.com.ua/ru/homepage/2010-01-26-13-42-29 (дата звернення: 27.07.2018).

11. Статистичний щорічник України за 2013 рік / за ред. О. Г Осауленка. К.: Державна служба статистики України, 2014. 534 с.

12. Ходаківська О.В., Корчинська С.Г. Ефективність застосування мінеральних і органічних добрив у сільському господарстві // Економіка АПК. 2016. №4. С.21-27.

13. Національна доповідь про стан навколишнього природного середовища у 2013 році / Міністерство екології та природних ресурсів України. Київ, 2015. 289 с.

Стаття надійшла 02.11.2018

Стаття прийнята до друку 16.11.2018

Доступно в мережі Internet 29.12.2018

\author{
Никишина О.В. \\ доктор экономических наук, старший научный сотрудник \\ отдел рыночных механизмов и структур \\ Институт проблем рынка и экономико-экологических исследований НАН Украины \\ Французский бульвар, 29, г.Одесса, Украина, 65044 \\ E-mail: ksenkych@gmail.com
}

\section{МЕТОДИЧЕСКИЕ ПОЛОЖЕНИЯ ПО МОНИТОРИНГУ ИНДИКАТОРОВ «ЗЕЛЕНОГО» РОСТА В КОНТЕКСТЕ УСТОЙЧИВОГО РАЗВИТИЯ УКРАИНЫ}

В статье обоснован методологический подход к мониторингу «зеленых» индикаторов на принципах устойчивого развития, объединивший концептуальный и методический базис. Определены научные принципы мониторинга прогресса «зеленого» роста, а именно: (1) системность и комплексность; (2) адекватность и гибкость; (3) объективность и точность; (4) действенность; (5) целенаправленность; (6) приоритетность экономических интересов государства; (7) научность.

Автором предложено расширенную систему экономико-экологических индикаторов для оценки достижения второй Цели устойчивого развития «Преодоление голода, развитие сельского хозяйства» в разрезе четырех заданий: (1) обеспечение доступности сбалансированного питания для всех слоев населения; (2) двойной рост производительности сельского хозяйства; (3) обеспечение создания устойчивых систем производства продуктов питания; (4) снижение волатильности цен на продукты питания. Акцентировано внимание на группу показателей органического земледелия, включившую ряд базовых индексов и показателей структуры.

На основе разработанной системы индикаторов проведен мониторинг их состояния в Украине за период 2005-2017 гг., что позволило определить динамику их изменений и степень достижения целевого значения показателей. По результатам мониторинга установлено, что в большинстве случаев наблюдается негативная тенденция снижения основных показателей, уровень которых ниже целевого значения индикаторов 2020 года. Исключение составляет группа индикаторов органического земледе- 
лия, которая имеет значительный потенциал роста и достижения целевых ориентиров устойчивого развития. Также значительный потенциал роста имеют показатели производства и экспорта продуктов питания.

Развитию украинского рынка органической продукции будет способствовать совершенствование институциональной среды и реализация механизмов стимулирования внутреннего спроса на органические товары, формирование системы государственных «зеленых» закупок. Переориентация отечественного экспорта с сырья на продукты ее переработки с высокой добавленной стоимостью предполагает изменение приоритетов государственной агропродовольственной политики.

Научная новизна проведенного исследования состоит в совершенствовании методического обеспечения мониторинга индикаторов «зеленого» роста на основе устойчивого развития. Перспективы дальнейших исследований заключаются в расширении системы базовых индикаторов целей устойчивого развития в Украине, развитии и апробации методик их мониторинга.

Ключевые слова: мониторинг, «зеленый» рост, устойчивое развитие, индикаторы, оценка, диагностика, «зеленая» трансформация.

\author{
Nikishina 0. \\ Doctor of Economics, Senior Researcher \\ Department of Market Mechanisms and Structures \\ Institute of Market Problems and Economic \& Ecological Research \\ of National Academy of Sciences of Ukraine \\ Frantsuzskiy boulevard, 29, Odesa, Ukraine, 65044 \\ E-mail: ksenkych@gmail.com
}

\title{
METHODICAL PROVISIONS ON MONITORING THE INDICATORS OF «GREEN» GROWTH IN THE CONTEXT OF SUSTAINABLE DEVELOPMENT OF UKRAINE
}

The article substantiates the methodological approach to the monitoring of «green» indicators on the basis of sustainable development, which combines the conceptual and methodical basis. The scientific principles of monitoring the progress of «green» growth have been defined, namely: (1) consistency and complexity; (2) adequacy and flexibility; (3) objectivity and accuracy; (4) efficacy; (5) purposefulness; (6) priority of economic interests of the state; (7) science.

The author proposed an expanded system of economic and environmental indicators to assess the achievement of the second goal of sustainable development «Overcoming hunger, development of agriculture» in the context of four tasks: (1) ensuring the availability of balanced nutrition for all segments of the population; (2) the double growth of agricultural productivity; (3) ensuring the establishment of sustainable food production systems; (4) reducing the volatility of food prices. The focus was made on a group of indices of organic farming, which included a number of basic indices and indicators of the structure.

On the basis of the developed system of indicators, monitoring of their state in Ukraine for the period of 2005-2017 was made, which allowed to determine the dynamics of their changes and the degree of achievement of the target value of the indicators. According to the monitoring results, in most cases there is a negative tendency to decrease the main indicators, the level of which is lower than the target value of 2020 indicators. An exception is a group of indicators of organic farming, which has significant potential for growth and achievement of sustainable development benchmarks. There is also a significant growth potential in terms of production and export of food.

The development of the Ukrainian market for organic products will be facilitated by the improvement of the institutional environment and the implementation of mechanisms for stimulating domestic demand for organic products, the formation of a system of state «green» procurement. The reorientation of domestic exports from raw materials to products of its processing with high added value implies a change in the priorities of the state agro-food policy.

The scientific novelty of the fulfilled study is to improve the methodical support for monitoring the indicators of «green» growth on the basis of sustainable development. Prospects for further research are to expand the system of basic indicators of the goals of sustainable development in Ukraine, to develop and test the methods of their monitoring.

Keywords: monitoring, «green» growth, sustainable development, indicators, assessment, diagnosis, «green» transformation. 


\section{References}

1. Dopovid' pro zelenu transformacîu v Ukraïnì na osnovì pokaznikìv zelenogo zrostannâ OESR. (pp. 1-60). (2016). Mìnìsterstvo ekonomìčnogo rozvitku ì torgìvlì Ukraïni.

2. Cili Stalogo Rozvitku: Ukrä̈na: Nacional'na dopovid' 2017. (pp. 1-176). (2017). Mìnìsterstvo ekonomǐnnogo rozvitku ì torgìvlì Ukraïni.

3. Cìli stalogo rozvitku dlâ Ukraïni: Regional'nij vimìr: Analitična dopovid'. (pp. 1-90). (2018). Lvìv: DU «Ìnstitut regìonal'nih doslìdžen' ìm. M.Ì. Dolì n'ogo NAN Ukraïni».

4. Balansi ta spoživannâ osnovnih produktìv harčuvannâ naselennâm Ukrä̈ni (pp. 1-59). (2018). Kyiv: Deržavna slu ba statistiki Ukraïni.

5. Ofìcìnij sajt Der avnoï slu bi statistiki Ukraïni. Retrieved November 01, 2018, from http://www.ukrstat.gov.ua/

6. Ofìcìnij sajt urnalu «Propozicì ». (2018). Retrieved November 01, 2018, from https://propozitsiya.com/ua/opublikovano-globalnyy-indeks-prodovolchoyi-bezpeky-za-2018-rik

7. Sil's'ke gospodarstvo Ukraïni u 2017 roci (pp. 1-245). (2018). Kyiv: Deržavna slu ba statistiki Ukraïni.

8. Verner, I. Ye. (Ed.). (2017). Statističnij ŝrö̌̌nik Ukraïni za 2016 rik (pp. 1-610). Kyiv: Der avna slu ba statistiki Ukraïni.

9. Verner, I. Ye. (Ed.). (2018). Ukraïna u cifrah 2017 (pp. 1-241). Kyiv: Der avna slu ba statistiki Ukraïni.

10. Ofìcìjnij sajt Federaciï organìčnogo ruhu v Ukraïnì: Organìk v Ukraïnì. Retrieved July 27, 2018, from http://organic.com.ua/ru/homepage/2010-01-26-13-42-29

11. Osaulenko, O. H. (Ed.). (2014). Statističnij ŝoričnik Ukraïni za 2013 rik (pp. 1-534). Kyiv: Der avna slu ba statistiki Ukraïni.

12. Khodakivska, O. V., \& Korchynska, S. H. (2016). Efektivnìst' zastosuvannâ mìneral'nih ì organǐčnih dobriv u sil's'komu gospodarstvì. Ekonomika APK, (4), 21-27.

13. Nacional'na dopovid' pro stan navkolišn'ogo prirodnogo seredoviŝa u 2013 rocì (pp. 1-289). (2015). Kyiv: Mìnìsterstvo ekologï ta prirodnih resursìv Ukraïni

Received 2 November 2018

Approved 16 November 2018

Available in Internet 29.12.2018

Цитування згідно ДСТУ 8302:2015

Нікішина О. В. Методичні положення щодо моніторингу індикаторів «зеленого» зростання у контексті сталого розвитку України // Економіка харчової промисловості. 2018. Т.10, вип. 4. С. 15-28. doi: 10.15673/fie.v10i4.1134

Cite as APA style citation

Nikishyna O. (2018). Methodical provisions on monitoring the indicators of «green» growth in the context of sustainable development of Ukraine. Food Industry Economics, 10(4), 15-28; doi: 10.15673/fie.v10i4.1134 